\title{
$\beta$-Sitosterolemia and Xanthomatosis
}

\author{
A NEWLY DESCRIBED LIPID STORAGE DISEASE \\ IN TWO SISTERS
}

\author{
Ashim K. Bhattacharyya and William E. Connor \\ From the Clinical Research Center and the Department of Internal Medicine, \\ University of Iowa College of Medicine, Iowa City, Iowa 52240
}

A B S T R A C T Although the usual diet may contain $150-250 \mathrm{mg}$ of plant sterols, chiefly $\beta$-sitosterol, only trace amounts of these sterols have heretofore been found in human or animal blood and tissues. We now report elevated plant sterol levels in the blood and tissues of two sisters with extensive tendon xanthomas but normal plasma cholesterol levels. Besides. $\beta$-sitosterolemia and xanthomatosis, no other physical, mental, or biochemical abnormalities were detected.

Repeatedly, the plasmas of the two sisters have contained 27.1 and $17.7 \mathrm{mg} / 100 \mathrm{ml}$ of $\beta$-sitosterol, 9.7 and $8.2 \mathrm{mg} / 100 \mathrm{ml}$ of campesterol, and 0.5 and $0.5 \mathrm{mg} / 100$ $\mathrm{ml}$ of stigmasterol, respectively. These plant sterols constituted 15.6 and $11.3 \%$ of the total plasma sterols. Some $60 \%$ of the plasma $\beta$-sitosterol and campesterol was esterified; the measurable stigmasterol was entirely unesterified. The transport of the plasma $\beta$-sitosterol and campesterol was largely in low density lipoproteins (76 and $83 \%$, respectively). High density lipoproteins carried the remainder. Plant sterols were barely detectable in the very low density lipoprotein fraction. Only trace amounts of stigmasterol could be detected in the low density and high density lipoprotein fractions. The plant sterol content of the red blood cells averaged $12-13 \mathrm{mg} / 100 \mathrm{ml}$ packed cells or about $13 \%$ of the total sterols. Two tendon xanthoma biopsies with the usual high concentration of cholesterol had 36.7 and $4.0 \mathrm{mg}$ of plant sterols/g dry wt, of which 25.7 and $2.9 \mathrm{mg}$ were $\beta$-sitosterol, entirely in the free form. Plant sterols were also found in adipose tissue

This work was presented in part at the 65th Annual Meeting of the American Society for Clinical Investigation, Atlantic City, N. J., 30 April 1973 (J. Clin. Invest. $52,9 a)$.

Received for publication 24 September 1973 and in revised form 26 November 1973.
(0.2 $\mathrm{mg} / \mathrm{g}$ wet $\mathrm{wt}$ ) and in skin surface lipids (3.2 $\mathrm{mg} / \mathrm{g}$ of lipid).

The intestinal absorption of $\beta$-sitosterol in both the patients, measured by two techniques, indicated greatly increased absorption of this sterol (about 24 and $28 \%$ in the patients L. $H$. and $R$. $H$., respectively, normal absorption being $<5 \%$ ). We suggest that increased absorption of $\beta$-sitosterol must be considered as one cause of this disease.

The reason for the extensive xanthomatosis in these two patients remains unknown. Perhaps in some way plant sterols initiated the development of xanthomas with otherwise normal plasma cholesterol levels. Clinical atherosclerosis has not yet occurred. The occurrence of $\beta$-sitosterolemia in these two sisters with unaffected parents suggests an inherited recessive trait.

\section{INTRODUCTION}

High concentrations of plant sterols in the blood and tissues of man and animals have not been previously reported. These sterols are usually found only in the lipids of plants and thus are particularly plentiful in vegetable oils, nuts, and other vegetable products. Structurally, the three plant sterols- $\boldsymbol{\beta}$-sitosterol, campesterol, and stigmasterol-resemble cholesterol except for minor differences in their side chains (Fig. 1). $\beta$-sitosterol and stigmasterol, both $C_{20}$ sterols, have an ethyl group at the C-24 position; stigmasterol, in addition, has a double bond at the $\mathrm{C}-22$ position. Campesterol, a $C_{23}$ sterol, has a methyl group at the C-24 position.

Plant sterols are habitually consumed by man in the usual diet. A typical American diet may contain up to $250 \mathrm{mg}$ of these sterols/day (1). $\beta$-Sitosterol is the predominant plant sterol, with campesterol the next 


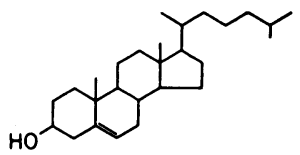

CHOLESTEROL $\left(\mathrm{C}_{27} \mathrm{H}_{46} \mathrm{O}\right)$ mol. wt. 386.6

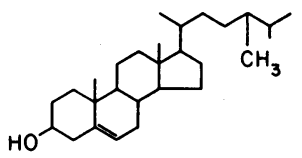

CAMPESTEROL $\left(\mathrm{C}_{28} \mathrm{H}_{48} \mathrm{O}\right)$

mol. wf. 400.7

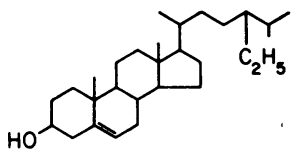

B-SITOSTEROL $\left(\mathrm{C}_{29} \mathrm{H}_{50} \mathrm{O}\right)$

mol. wt. 414.7

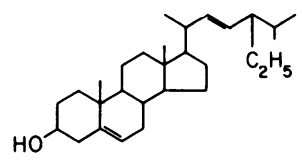

STIGMASTEROL $\left(\mathrm{C}_{29} \mathrm{H}_{48} \mathrm{O}\right)$

mol. wt. 412.7
Figure 1 The chemical structures of cholesterol and plant sterols.

most abundant, and stigmasterol the least. These sterols pass through the intestinal tract almost completely unabsorbed and are usually recovered quantitatively in the feces. The intestinal absorption in man that does occur has been estimated at less than $5 \%$ of the amount in the diet, and only very small amounts of plant sterols are detectable in the blood $(2,3)$.

In this communication, we report for the first time high concentrations of $\beta$-sitosterol and the two other plant sterols in the blood and tissues of two sisters. The plant sterols were found to be widely distributed: in the plasma, lipoproteins, red blood cells, xanthoma, adipose tissue, and skin surface lipids. The intestinal absorption of $\beta$-sitosterol was greatly increased, thus suggesting that one mechanism for the $\beta$-sitosterolemia was enhanced intestinal absorption of $\beta$-sitosterol from the diet. Furthermore, we postulate that in some way plant sterols initiated the development of the xanthomas in these two sisters, whose serum lipid levels were otherwise normal.

\section{METHODS}

The description of the patients. The patients of this report were two Caucasian sisters, L. H. and R. H., who were university students (Table I). About 2 yr ago, patient $\mathrm{L}$. $\mathrm{H}$. attended the orthopedic clinic of the University Hospitals with a chief complaint of pains in both heels and knees. Tendon xanthomas were discovered, and she was referred to us for further investigations. Clinical history revealed that tendon xanthomas were first noted at the age of $8 \mathrm{yr}$ in the extensor tendons of both hands. No treatment was given. Subsequently, over the years, xanthomas developed in the patellar, plantar, and Achilles tendon. Her younger sister, R. H., also had extensive tendon and tuberous xanthomas dating back to childhood. An excision biopsy of one lesion at that time indicated a "xanthoma." Patient R. H., when subsequently examined by us, was likewise found to have large xanthomas of the Achilles: plantar, and patellar tendons and of the extensor tendons of the hand. There were tuberous xanthomas of the elbows.

Aside from the xanthomas, their physical examinations and initial laboratory tests were normal. Dietary history revealed that both sisters were consuming the usual American diet. Their habitual diet provided an estimated plant sterol intake of $150-250 \mathrm{mg} /$ day.

The family history indicated that the parents and the grandparents had no evidence of xanthomas. The parents were of German and Swiss-German origin. There was no history of consanguinity in the family. The two sisters were the only children in the family.

TABLE I

Clinical Description of the Two Sisters with $\beta$-Sitosterolemia and Xanthomatosis

\begin{tabular}{|c|c|c|}
\hline & Patient L. H. & Patient R. H. \\
\hline Age, $y \mathrm{r}$ & 22 & 20 \\
\hline Height, $\mathrm{cm}$ & 165 & 165 \\
\hline Weight, $k g$ & 62 & 58 \\
\hline \multicolumn{3}{|l|}{ Xanthoma } \\
\hline \multicolumn{3}{|l|}{ First appearance: } \\
\hline Tuberous & & \multirow{2}{*}{$\begin{array}{l}\text { At } 7 \mathrm{yr} \text {, both elbows } \\
\text { At } 7 \mathrm{yr} \text {, achilles }\end{array}$} \\
\hline Tendon & $\begin{array}{l}\text { At } 8 \mathrm{yr} \text {, extensor tendons of } \\
\text { both hands } \\
\text { At } 14 \mathrm{yr} \text {, Achilles }\end{array}$ & \\
\hline \multicolumn{3}{|l|}{ At present } \\
\hline Tuberous & Both elbows & Both elbows, on both knees \\
\hline Tendon & $\begin{array}{l}\text { Extensor tendons of both } \\
\text { hands, patellar, Achilles }\end{array}$ & $\begin{array}{l}\text { Extensor tendons of both hands } \\
\text { patellar, plantar, Achilles, } \\
\text { both elbows }\end{array}$ \\
\hline \multicolumn{3}{|c|}{ Plasma lipids, $\mathrm{mg} / 100 \mathrm{ml}$} \\
\hline Cholesterol & 195 & 206 \\
\hline 'Triglycerides & 81 & 63 \\
\hline
\end{tabular}


Determinations of sterols in plasma, erythrocytes, and tissues. $0.5 \mathrm{ml}$ of plasma or serum was saponified and extracted with hexane after the procedure of Abell, Levy, Brodie, and Kendall (4). The hexane extract was evaporated to dryness and analyzed by gas-liquid chromatography (GLC) ${ }^{1}$ as trimethylsilyl ether (TMS) derivative (5), with $5 \alpha$-cholestane used as the internal standard. The erythrocytes were washed repeatedly with $0.9 \%$ sodium chloride solution, and the lipids were extracted with chloroform: isopropranol (7:11, vol/vol) (6). An aliquot of the extract was then subjected to GLC analysis as described above. Free and esterified sterols in plasma and erythrocyte were separated by thin-layer chromatography (TLC) using Silica-Gel G plates. The plates were developed in petroleum ether-diethyl ether-glacial acetic acid, $80: 20: 1$. The free and ester sterol bands were scraped off and eluted with diethyl ether. The free sterol band eluate was subjected to GLC analysis directly, whereas the ester sterol band eluate was saponified, extracted with hexane, and then subjected to GLC analysis as described above.

Very low density lipoproteins (VLDL) were isolated by preparative ultracentrifugation from $6 \mathrm{ml}$ of plasma (7). The infranate was made up to $5 \mathrm{ml}$ and divided into two equal parts. From one, high density lipoprotein (HDL) fraction was obtained by precipitating low-density lipoprotein (LDL) with heparin and manganese chloride solution (8). The VLDL fraction, the fraction containing LDL and HDL, and the HDL fraction were separately extracted with chloroform: methanol $(2: 1, \mathrm{vol} / \mathrm{vol})$ and made up to a suitable volume with the solvent. Aliquots of the extracts were taken for sterol analysis by GLC. The sterol value for $L D L$ was obtained by subtracting the HDL sterol from that of the combined HDL + LDL fraction.

Patient R. H. underwent surgical removal of xanthomas from the patellar and the plantar tendons (through the cooperation of Dr. A. E. Flatt, Department of Orthopaedics). The tissue specimens were cut into small pieces and washed repeatedly with $0.9 \%$ sodium chloride solution to remove any blood. The pieces were blotted on a filter paper, weighed, and dried in a hot oven vacuum dessicator at $80^{\circ} \mathrm{C}$ to a constant weight. The dried tissues were repeatedly extracted with chloroform:methanol by boiling, and the lipid extracts were made up to $100 \mathrm{ml}$. Aliquots were taken for total, free, and esterified sterol determinations as described above. A sample of adipose tissue from patient R. H. was obtained by needle aspiration (9) for sterol analysis as described above.

In vitro plasma esterification of sterols. Blood samples in EDTA, $1 \mathrm{mg} / \mathrm{ml}$ blood were obtained from patient $\mathrm{R}$. $\mathrm{H}$. and two normal subjects (W. C. and A. B.), all in the fasting state. The plasma was added to a tube containing a known quantity of $\left[4-{ }^{14} \mathrm{C}\right] \beta$-sitosterol ${ }^{2}(20,048 \mathrm{dpm} / \mathrm{ml})$ and $\left[1-2-^{2} \mathrm{H}\right]$ cholesterol $^{3}(20,208 \mathrm{dpm} / \mathrm{ml})$ and mixed thoroughly. $0.5 \mathrm{ml}$ of the plasma was immediately pipetted out

${ }^{1}$ Abbreviations used in this paper: GLC, gas-liquid chromatography; HDL, high density lipoprotein; LCAT, lecithin-cholesterol acyl transferase; LDL, low density lipoprotein; TLC, thin-layer chromatography; TMS, trimethylsilyl ether; VLDL, very low density lipoprotein.

'Obtained from Amersham/Searle Corp., Arlington Heights, Ill.

3 Obtained from New England Nuclear, Boston, Mass. The radio-purity of both sterols was $>98 \%$ as checked by TLC and GLC.
TABLE II

Test Breakfast for Sitosterol Absorption

\begin{tabular}{lc}
\hline \multicolumn{1}{c}{ Substance } & Amount \\
\hline Calories & 800 \\
Carbohydrate & $63 \mathrm{~g}$ \\
Protein & $25 \mathrm{~g}$ \\
Fat & $50 \mathrm{~g}$ \\
Mono-unsaturated & $18.3 \mathrm{~g}$ \\
Saturated & $16.6 \mathrm{~g}$ \\
Polyunsaturated & $15.1 \mathrm{~g}$ \\
Cholesterol & $0 \mathrm{mg}$ \\
Plant sterols & $3,500 \mathrm{mg}$ \\
$\beta$-Sitosterol & $2,400 \mathrm{mg}$ \\
Campesterol & $1,000 \mathrm{mg}$ \\
Stigmasterol & $100 \mathrm{mg}$ \\
Isotope: $\left[4-{ }^{14} \mathrm{C}\right] \beta$-sitosterol & $2.0 \mu \mathrm{Ci}$ \\
\hline
\end{tabular}

and extracted as above. The rest were incubated at $37^{\circ} \mathrm{C}$ in a Dubnoff metabolic shaker, and at intervals of 24 and $48 \mathrm{~h} 0.5-\mathrm{ml}$ aliquots were taken out and extracted with chloroform: methanol. Free and ester sterols were determined as described above, and the radioactivity was determined on another portion with $10 \mathrm{ml}$ of scintillation solution (4 $\mathrm{g}$ of 2,5-diphenyloxazole and $0.1 \mathrm{~g}$ of 1,4-bis(2(5-phenyloxazolyl) benzene)/liter of toluene), in a Packard Tri-Carb liquid scintillation counter (model 3380, Packard Instrument Co., Inc., Downers Grove, Ill.) equipped with external standardization.

Sterols of the skin surface lipids. Two overnight collections of skin surface lipids were carried out on each patient after the procedure described previously (5). Sterol analyses were carried out by combination of TLC and GLC (5).

$\beta$-Sitosterol intestinal absorption. The intestinal absorption of $\beta$-sitosterol was measured in both patients by feeding a single dose of $\beta$-sitosterol (about $2,500 \mathrm{mg}$ and 2.0 $\mu \mathrm{Ci}$ of $\left[4-^{14} \mathrm{C}\right] \beta$-sitosterol) in a formula breakfast (Table II). The isotope was first dissolved in $5 \mathrm{~g}$ peanut oil with $150 \mathrm{mg}$ crystalline $\beta$-sitosterol added as carrier and then mixed with the formula, which contained a total of 2,500 $\mathrm{mg}$ of $\beta$-sitosterol. An aliquot of the formula was analyzed for sterol mass and radioactivity to obtain the exact amounts fed (10). The feces were collected daily for the following 7-8 days and homogenized with $1: 1$ water as a single pool, and an aliquot was analyzed for sterol mass and radioactivity (10). The absorption of $\beta$-sitosterol was calculated as the difference between the amount fed and the amount excreted in the feces and expressed as percent of the intake (11). By this technique absorption was measured for both mass and radioactivity. The amount of $\beta$ sitosterol ingested daily in the background diet was considered in the calculations for mass. Fasting blood samples were also obtained subsequently for the determination of plant sterol radioactivity.

Patient $R$. H. received a second and larger test dose of about $60 \mu \mathrm{Ci}$ of $\left[4-{ }^{14} \mathrm{C}\right] \beta$-sitosterol in approximately $100 \mathrm{ml}$ of skim milk with a breakfast that provided a total of 535 calories, $70 \mathrm{~g}$ carbohydrate, $21 \mathrm{~g}$ protein, $19 \mathrm{~g}$ fat, and 225 mg of cholesterol. This study was performed as a second test of absorption and to follow more accurately the appearance of $\left[4^{14} \mathrm{C}\right] \beta$-sitosterol in the blood. 
TABLE III

Plasma Total, Free, and Esterified Plant Sterols and Cholesterol in the Two Sisters

\begin{tabular}{|c|c|c|c|c|c|c|c|c|c|c|c|c|c|c|}
\hline \multirow[b]{3}{*}{ Patient } & \multirow{3}{*}{$\begin{array}{l}\text { Date of } \\
\text { sample }\end{array}$} & \multirow{3}{*}{$\begin{array}{c}\text { Total } \\
\text { plant } \\
\text { sterols }\end{array}$} & \multicolumn{9}{|c|}{ Plant sterols } & & & \\
\hline & & & \multicolumn{3}{|c|}{$\beta$-Sitosterol } & \multicolumn{3}{|c|}{ Campesterol } & \multicolumn{3}{|c|}{ Stigmasterol } & \multicolumn{3}{|c|}{ Cholesterol } \\
\hline & & & Total & Free & Ester & Total & Free & Ester & Total & Free & Ester & Total & Free & Ester \\
\hline & & & \multicolumn{12}{|c|}{$m g / 100 \mathrm{ml}$} \\
\hline \multirow[t]{3}{*}{ L. H. } & $5-18-72$ & 32.2 & 24.5 & 9.4 & 15.1 & 7.5 & 2.6 & 5.0 & 0.2 & 0.2 & Trace* & 162.8 & 40.7 & 122.1 \\
\hline & $2-25-72$ & 39.4 & 28.9 & 16.3 & 12.5 & 10.4 & 5.7 & 4.7 & 0.1 & 0.1 & Trace & 204.8 & 74.6 & 130.2 \\
\hline & $8-29-72$ & 40.3 & 28.0 & 10.4 & 17.8 & 11.1 & 3.6 & 7.5 & 1.2 & 1.2 & Trace & 212.6 & 53.3 & 159.3 \\
\hline \multicolumn{2}{|c|}{ Mean $\pm S D$} & $37.3 \pm 4.4$ & $27.1 \pm 2.3$ & $12.0 \pm 3.7$ & $15.1 \pm 2.6$ & $9.7 \pm 1.9$ & $4.0 \pm 1.6$ & $5.7 \pm 1.5$ & $0.5 \pm 0.6$ & $0.5 \pm 0.6$ & Trace & $193.4 \pm 26.8$ & $56.2 \pm 17.1$ & $137.1 \pm 19.6$ \\
\hline \multirow[t]{3}{*}{ R. H. } & $4-7-72$ & 24.0 & 16.3 & 8.1 & 8.1 & 7.6 & 3.6 & 4.0 & 1.0 & 1.0 & Trace & 183.1 & 33.3 & 149.8 \\
\hline & $5-18-72$ & 28.4 & 19.5 & 7.2 & 12.3 & 8.7 & 3.0 & 5.7 & 0.2 & 0.2 & Trace & 233.4 & 62.1 & 171.3 \\
\hline & $6-15-72$ & 26.0 & 17.4 & 6.7 & 10.7 & 8.3 & 2.8 & 5.4 & 0.3 & 0.3 & Trace & 200.5 & 53.4 & 147.1 \\
\hline \multicolumn{2}{|c|}{ Mean $\pm \mathrm{SD}$} & $26.1 \pm 2.2$ & $17.7 \pm 1.6$ & $7.3 \pm 0.7$ & $10.4 \pm 2.1$ & $8.2 \pm 0.5$ & $3.1 \pm 0.4$ & $5.0 \pm 0.9$ & $0.5 \pm 0.4$ & $0.5 \pm 0.4$ & Trace & $205.7 \pm 25.5$ & $49.6 \pm 14.8$ & $156.1 \pm 13.3$ \\
\hline
\end{tabular}

* Indicates $<0.01 \mathrm{mg} / 100 \mathrm{ml}$.

\section{RESULTS}

Plant sterols were found in relatively high concentrations in the plasmas of both sisters (Table III). On repeated determinations, the total plasma plant sterol concentration was $37.3 \mathrm{mg} / 100 \mathrm{ml}$ in patient $\mathrm{L}$. H. and constituted $16.2 \%$ of the total plasma sterols. These were distributed as $27.1 \mathrm{mg} / 100 \mathrm{ml} \beta$-sitosterol, $9.7 \mathrm{mg} / 100 \mathrm{ml}$ campesterol, and $0.5 \mathrm{mg} / 100 \mathrm{ml}$ stigmasterol. The plasma cholesterol in patient L. H. was $193 \mathrm{mg} / 100 \mathrm{ml}$ or about $84 \%$ of the total plasma sterols. Similarly, in the sister, R. H., the total plasma plant sterols were $26.1 \mathrm{mg} / 100 \mathrm{ml}$ or $11.3 \%$ of total plasma sterols. These were distributed as $17.7 \mathrm{mg} / 100$ $\mathrm{ml} \beta$-sitosterol, $8.2 \mathrm{mg} / 100 \mathrm{ml}$ campesterol, and 0.5 $\mathrm{mg} / 100 \mathrm{ml}$ stigmasterol. The plasma cholesterol concentration in patient $\mathrm{R}$. H. was $206 \mathrm{mg} / 100 \mathrm{ml}$, constituting about $89 \%$ of the total plasma sterols. The total plasma plant sterol concentration of their father was $0.19 \mathrm{mg} / 100 \mathrm{ml}$, and that of the mother was 0.27 $\mathrm{mg} / 100 \mathrm{ml}$ : barely detectable amounts. The total plasma plant sterol content in normal subjects, determined in our laboratory, averaged $0.67 \pm 0.09 \mathrm{mg} / 100 \mathrm{ml}$.

Both the plasma $\beta$-sitosterol and campesterol were largely esterified : 57 and $60 \%$ of their respective total amounts (Table III). The amount of esterification was similar for both patients. The plasma stigmasterol, found in very small quantities, was measured only in the free form $(0.5 \mathrm{mg} / 100 \mathrm{ml})$. In comparison, the plasma esterified cholesterol constituted 71.2 and $76.2 \%$ of the total cholesterol in L. H. and R. H., respectively.

The red blood cell content of plant sterols was 12-13 $\mathrm{mg} / 100 \mathrm{ml}$ of packed cells for both sisters, about $13 \%$ of the total erythrocyte sterols (Table IV). Red cell cholesterol concentration was, on the average, $83 \mathrm{mg} /$ $100 \mathrm{ml}$ packed cells or $87 \%$ of the total sterols. All red cell sterols were entirely in the free form. The cholesterol-to- $\beta$-sitosterol ratio in the red blood cells was nearly similar to the ratio in the plasma: 933 $\pm 22 \%$ in the red blood cells and $1,157 \pm 37$ in the plasma. This suggests free exchange of both sterols between the plasma and the red blood cells.

The plasma plant sterols were mainly transported in low density and high density lipoproteins. The very low density lipoproteins of both sisters carried only trace amounts of plant sterols (Table V). The low density lipoprotein $\beta$-sitosterol was 82 and $70 \%$ of total plasma $\beta$-sitosterol concentration in $\mathrm{L}$. H. and $\mathrm{R}$. H. respectively, very similar to the concentration of low density

TABLE IV

Red Blood Cell Sterols in the Two Sisters

\begin{tabular}{lccccc}
\hline & \multicolumn{4}{c}{ Plant sterols } & \\
\cline { 2 - 4 } Patient & Total & $\beta$-Sitosterol & Campesterol & Stigmasterol & Cholesterol \\
\hline & & \multicolumn{4}{c}{$m g / 100 \mathrm{ml}$ packed cells } \\
L. H. & 12.1 & 7.0 & 3.1 & 1.0 & 82.2 \\
R. H. & $13.6 \pm 2.0^{*}$ & $8.8 \pm 1.2$ & $4.0 \pm 0.5$ & $0.7 \pm 0.4$ & $84.3 \pm 9.6$ \\
\hline
\end{tabular}

* Mean $\pm \mathrm{SD}$ of three determinations. 
TABLE V

The Distribution of Plant Sterols and Cholesterol in the Plasma* Lipoprotein Fractions of the Two Sisters

\begin{tabular}{|c|c|c|c|c|c|c|c|c|c|c|}
\hline \multirow[b]{3}{*}{ Patient } & \multirow{2}{*}{\multicolumn{2}{|c|}{ Very low density lipoprotein }} & \multicolumn{4}{|c|}{ Low density lipoprotein $\ddagger$} & \multicolumn{4}{|c|}{ High density lipoprotein $\ddagger$} \\
\hline & & & \multicolumn{3}{|c|}{ Plant sterols } & \multirow[b]{2}{*}{ Cholesterol } & \multicolumn{3}{|c|}{ Plant sterols } & \multirow{2}{*}{ Cholestero } \\
\hline & $\begin{array}{l}\text { Plant } \\
\text { sterols, } \\
\text { total }\end{array}$ & Cholesterol & Total & $\begin{array}{c}\beta \text {-Sito- } \\
\text { sterol }\end{array}$ & $\begin{array}{c}\text { Campes- } \\
\text { terol }\end{array}$ & & Total & $\begin{array}{c}\beta \text {-Sito- } \\
\text { sterol }\end{array}$ & $\begin{array}{c}\text { Campes- } \\
\text { terol }\end{array}$ & \\
\hline & \multicolumn{10}{|c|}{$m g / 100 \mathrm{ml}$} \\
\hline \multirow[t]{2}{*}{ L. H. } & Trace $\$$ & 12.1 & 32.9 & 20.4 & 12.5 & 194.5 & 6.5 & 4.3 & 3.3 & 29.5 \\
\hline & Trace & 4.9 & 31.9 & 22.2 & 9.7 & 177.3 & 5.9 & 4.9 & 1.0 & 33.6 \\
\hline \multirow[t]{2}{*}{ R. H. } & Trace & 8.3 & 14.5 & 7.9 & 6.6 & 128.6 & 8.5 & 6.0 & 2.5 & 66.8 \\
\hline & Trace & 4.3 & 17.6 & 10.9 & 6.7 & 136.2 & 3.3 & 2.2 & 1.1 & 53.6 \\
\hline
\end{tabular}

* Obtained on different days.

‡ Stigmasterol present in trace amounts $(<0.01 \mathrm{mg} / 100 \mathrm{ml})$.

Indicates $<0.01 \mathrm{mg} / 100 \mathrm{ml}$.

lipoprotein cholesterol in relation to total cholesterol (Fig. 2). 18 and $30 \%$ of the total plasma $\beta$-sitosterol in L. H. and R. H. were transported in high density lipoprotein. The percent low density lipoprotein campesterol was 87.4 and 85.8 in L. H. and R. H., respectivelya little higher than that of cholesterol and $\beta$-sitosterol. About $13 \%$ of the total plasma campesterol was transported in the high density lipoprotein. Stigmasterol was only present in trace quantities in the lipoprotein fractions (Table V). The cholesterol distribution was normal: about $3 \%$ in very low density, $75 \%$ in low density, and $22 \%$ in high density lipoproteins.

The in vitro tests for esterification by the plasmas of R. H. and 2 normal control subjects indicated that $\boldsymbol{\beta}$-sitosterol was esterified by the plasmas of both $\mathrm{R}$. $\mathrm{H}$. and the controls (Fig. 3). The esterification of $\left[4-{ }^{14} \mathrm{C}\right]$ $\beta$-sitosterol by R. H. was slower than the esterification of both $\boldsymbol{\beta}$-sitosterol and cholesterol in the normal controls. However, the esterification of $\left[1,2-^{3} \mathrm{H}\right]$ cholesterol was similar in $\mathrm{R}$. H. as compared with normal controls.

After the in vitro incubation of R. H.'s plasma, the

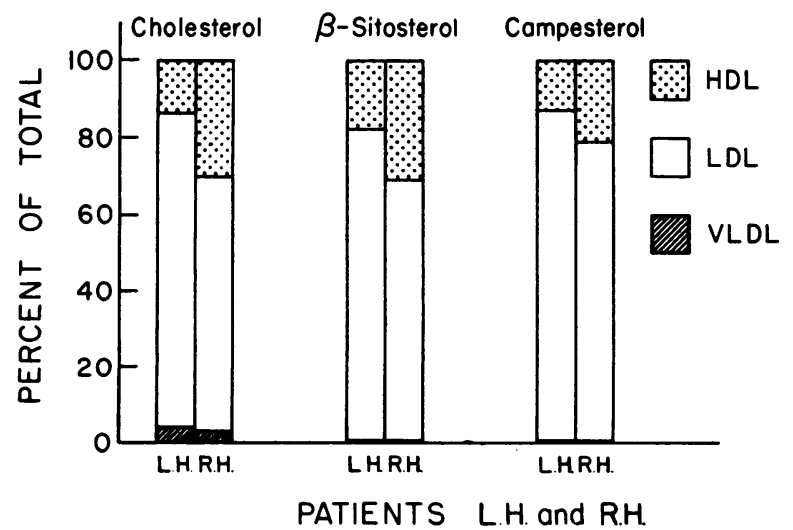

FIGURE 2 The distribution of sterols in the plasma lipoproteins of the two sisters. amounts of esterified plant sterols (campesterol and $\beta$-sitosterol) as well as cholesterol increased simultaneously, as the concentrations of the unesterified sterols decreased (Table VI). By mass determination, the ester/free ratios of the various sterols were about twice their initial values after $24 \mathrm{~h}$ of incubation: from 2.7 to 5.2 for $\beta$-sitosterol, from 1.7 to 4.3 for campesterol, and from 2.4 to 6.0 for cholesterol. An additional $24 \mathrm{~h}$ of incubation provided much smaller increases in these ester/free ratios. Lecithin-cholesterol acyl transferase (LCAT), the enzyme known to be the cholesterol-esterifying enzyme of the plasma (12), was probably responsible for the esterification of the plasma plant sterols.

Plant sterols were found in the two tendon xanthoma biopsies and in the adipose tissue of R. H. (Table VII). The plant sterol content of the patellar xanthoma was $36.7 \mathrm{mg}$, and that of the plantar xanthoma was $4.0 \mathrm{mg} / \mathrm{g}$ dry wt or $17.5 \%$ and $12.3 \%$ of the total sterol content. As in the plasma, $\beta$-sitosterol was the most plentiful $\left[4-{ }^{14} C\right] \beta-$ Sitosterol

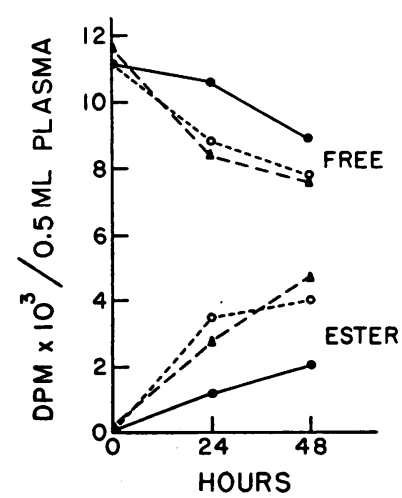

$\left[1,2-{ }^{3} \mathrm{H}\right]$ Cholesterol

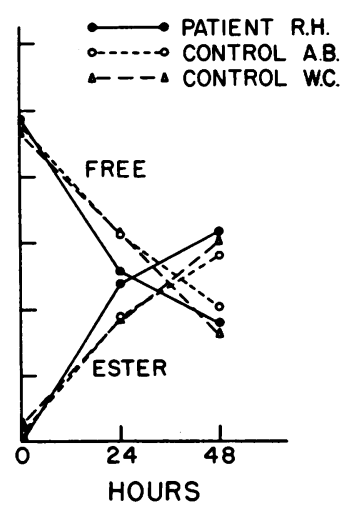

FIGURE 3 The in vitro esterification of $\left[4{ }^{11} \mathrm{C}\right] \beta$-sitosterol and $\left[1,2-{ }^{3} \mathrm{H}\right]$ cholesterol by the plasmas of $R$. H. and two normal control subjects (W. C. and A. B.). 
TABLE VI

The Changes in the Plasma Free and Ester Sterols Concentrations After In Vitro Incubalion

\begin{tabular}{|c|c|c|c|c|c|c|c|c|c|}
\hline & \multicolumn{3}{|c|}{ Patient R. H. } & \multicolumn{3}{|c|}{ Normal W. C.* } & \multicolumn{3}{|c|}{ Normal A. B.* } \\
\hline & $\mathrm{Oh}$ & $24 \mathrm{~h}$ & $48 \mathrm{~h}$ & $0 \mathrm{~h}$ & $24 \mathrm{~h}$ & $48 \mathrm{~h}$ & $\mathrm{Oh}$ & $24 \mathrm{~h}$ & $48 \mathrm{~h}$ \\
\hline Cholesterol & \multicolumn{9}{|c|}{$\mathrm{mg} / 100 \mathrm{ml}$} \\
\hline Ester/free & 2.4 & 6.0 & 6.7 & 3.1 & 6.6 & 8.0 & 2.5 & 6.5 & 7.6 \\
\hline Free & 55.5 & 26.8 & 24.6 & 43.7 & 23.1 & 19.6 & 58.4 & 27.5 & 23.6 \\
\hline Ester & 130.5 & 159.7 & 156.7 & 134.2 & 152.9 & 156.7 & 145.6 & 177.9 & 179.3 \\
\hline Total & 186.0 & 186.5 & 188.6 & 177.9 & 176.0 & 176.3 & 204.0 & 205.4 & 202.9 \\
\hline \multicolumn{10}{|l|}{$\beta$-Sitosterol } \\
\hline Ester/free & 2.7 & 5.2 & 6.3 & & & & & & \\
\hline Free & 3.9 & 2.4 & 2.1 & & & & & & \\
\hline Ester & 10.4 & 12.2 & 12.9 & & & & & & \\
\hline Total & 14.3 & 14.6 & 15.0 & & & & & & \\
\hline \multicolumn{10}{|l|}{ Campesterol } \\
\hline Ester/free & 1.7 & 4.3 & 4.6 & & & & & & \\
\hline Free & 2.6 & 1.2 & 1.2 & & & & & & \\
\hline Ester & 4.4 & 5.4 & 5.5 & & & & & & \\
\hline Total & 7.0 & 6.6 & 6.7 & & & & & & \\
\hline
\end{tabular}

*W. C. and A. B. had no detectable plasma plant sterols.

plant sterol in the patellar xanthoma, $25.7 \mathrm{mg} / \mathrm{g}$, followed by campesterol, $9.1 \mathrm{mg} / \mathrm{g}$, and stigmasterol, $1.9 \mathrm{mg} / \mathrm{g}$. The total sterol content was $210.1 \mathrm{mg}, 32.3 \mathrm{mg} / \mathrm{g}$ dry wt. Cholesterol made up the remainder of the total sterols. Only trace amounts $(<0.01 \mathrm{mg} / 100 \mathrm{ml})$ of plant sterol ester were found in the xanthomas. The cholesterol ester content of the two xanthomas was $8.5 \mathrm{mg}$ and 8.3 $\mathrm{mg} / \mathrm{g}$ dry $\mathrm{wt}$, or $4.9 \%$ and $29.4 \%$ of total cholesterol, respectively (Table VII). Adipose tissue contained 0.2 $\mathrm{mg} / \mathrm{g}$ wet wt of $\beta$-sitosterol, $17.9 \%$ of the total sterol concentrations. Only trace amounts of the other plant sterols could be detected. The percentage of $\beta$-sitosterol in adipose tissue sterols was slightly higher than that of the patient's plasma $(11.3 \%)$. These results indicate that the tissue cholesterol esterase did not esterify the plant sterols and apparently is sterol-specific as regards its substrate. In contrast, the plasma cholesterol-esterifying enzyme, LCAT, as shown above, probably did not distinguish between its substrates, namely, cholesterol, $\beta$-sitosterol, and campesterol.

In both sisters, plant sterols were found in the skin surface lipids, about $19 \%$ of the total sterols. $\beta$-Sitos-

TABLE VII

Tissue Sterols in Patient R. H.

\begin{tabular}{|c|c|c|c|c|c|c|c|c|c|c|}
\hline \multirow[b]{3}{*}{ Tissue } & \multicolumn{7}{|c|}{ Plant sterols } & & & \\
\hline & \multirow[b]{2}{*}{ Total } & \multicolumn{2}{|c|}{$\beta$-Sitosterol } & \multicolumn{2}{|c|}{ Campesterol } & \multicolumn{2}{|c|}{ Stigmasterol } & \multicolumn{3}{|c|}{ Cholesterol } \\
\hline & & Free & Ester & Free & Ester & Free & Ester & Total & Free & Ester \\
\hline & \multicolumn{10}{|c|}{$m g / g d r y w t$} \\
\hline Tendon xanthoma & & & & & & & & & & \\
\hline Patellar & $\begin{array}{c}36.7 \\
(17.5) \ddagger\end{array}$ & 25.7 & Trace* & 9.1 & Trace & 1.9 & Trace & $\begin{array}{l}173.4 \\
(82.5)\end{array}$ & 164.9 & 8.5 \\
\hline Plantar & $\begin{array}{r}4.0 \\
(12.3)\end{array}$ & 2.9 & Trace & 1.1 & 'Trace & Trace & Trace & $\begin{array}{c}28.3 \\
(87.7)\end{array}$ & 20.0 & 8.3 \\
\hline Adipose tissue & $\begin{array}{c}0.2 \\
(17.9)\end{array}$ & 0.2 & & Trace & & Trace & & $\begin{array}{c}0.7 \\
(82.1)\end{array}$ & & \\
\hline
\end{tabular}

* Indicates $<0.010 \mathrm{mg} / \mathrm{g}$ dry wt.

$\ddagger$ Figures in parentheses indicate percent of total sterols.

$\S$ Values are milligrams per gram wet wt. 


\section{TABLE'VIII}

The Plant Sterols and Other Sterols of the Skin Surface Lipids

\begin{tabular}{|c|c|c|c|c|c|c|c|}
\hline Patient & $\begin{array}{l}\text { Date of } \\
\text { collection }\end{array}$ & \multicolumn{4}{|c|}{ Plant sterols } & Cholesterol & Lathosterol \\
\hline & & \multicolumn{6}{|c|}{$\%$ of total sterols } \\
\hline \multirow[t]{2}{*}{ L. H. } & $8-28-72$ & 17.4 & 15.2 & 1.27 & 0.98 & 81.0 & 1.52 \\
\hline & $8-30-72$ & 20.1 & 17.5 & 1.40 & 1.18 & 78.3 & 1.58 \\
\hline R. H. & $9-13-72$ & 21.3 & 19.6 & 1.50 & 0.17 & 76.1 & 2.61 \\
\hline Normal subjects* & Mean $\pm S D$ & $7.5 \pm 2.6$ & $6.8 \pm 2.5$ & $0.3 \pm 0.1$ & $0.4 \pm 0.1$ & $90.3 \pm 2.9$ & $2.2 \pm 0.6$ \\
\hline
\end{tabular}

* From reference 5 .

terol was the primary plant sterol, constituting $16 \%$ of the total (Table VIII). More plant sterol was contained in the skin surface sterol than for normal persons; i.e., $19 \%$ of the total sterols versus the previously reported values of $7.5 \%$ in normal subjects (5).

The intestinal absorption of $\beta$-sitosterol in L. H. was $18 \%$ of the administered dose of $\beta$-sitosterol measured by mass. By radioactivity measurements, she absorbed a similar percentage, $29 \%$, of the dose (Table IX). R. H. absorbed $27 \%$ of the dose of $\beta$-sitosterol by mass and $29 \%$ by radioactivity measurement. At the time of the second test, R. H. absorbed $35 \%$ of the oral $\left[4-{ }^{14} \mathrm{C}\right]-$ $\beta$-sitosterol dose.

Another measure of intestinal absorption would be the amount of isotopic sitosterol that appeared in the blood after its oral administration in the test meal. In the second test $\mathrm{R}$. H. received $60.3 \mu \mathrm{Ci}$ of $\left[4-{ }^{14} \mathrm{C}\right] \beta$-sitosterol orally. At intervals of time from 2 to 9 days later, up to $7.1 \%$ of the total dose was present in her total

\section{TABLE IX}

The Intestinal Absorption of $\beta$-Sitosterol in Patients L. H. and R. H. After a Single Oral Test Meal by Mass and by $\left[4-{ }^{14} \mathrm{C}\right] \beta$-Sitosterol

\begin{tabular}{|c|c|c|c|}
\hline Patient & $\begin{array}{c}\beta \text {-Sitosterol } \\
\text { intake }\end{array}$ & $\begin{array}{c}\beta \text {-Sitosterol } \\
\text { excretion } \\
\text { in feces }\end{array}$ & $\begin{array}{c}\% \\
\text { absorption }\end{array}$ \\
\hline
\end{tabular}

By mass, $m g^{*}$

$\begin{array}{llll}\text { L. H. } & 3509 & 2892 & 18\end{array}$

$\begin{array}{llll}\text { R. H. } & 3037 & 2219 & 27\end{array}$

By $\left[4-{ }^{-14} \mathrm{C}\right] \beta$-Sitosterol, $\mu \mathrm{Ci}$

$\begin{array}{lrrr}\text { L. H. } & 1.90 & 1.34 & 29 \\ \text { R. H. } & 1.93 & 1.37 & 29 \\ & 60.30 & 39.20 & 35\end{array}$

* Total amount present in the test breakfast plus the daily intake contained in the usual diet. plasma volume compared with less than $0.2 \%$ of the administered dose of $\left[4-{ }^{14} \mathrm{C}\right]$ sitosterol in the plasma of a normal subject who received a comparable test meal (Table $\mathrm{X}$ ). In other words, about 35 times more radioactivity after an oral dose of $\left[4-{ }^{14} \mathrm{C}\right] \beta$-sitosterol appeared in the plasma of R. H., compared to the normal subject. This data provides additional evidence for the increased intestinal absorption of dietary $\beta$-sitosterol.

The $\boldsymbol{\beta}$-sitosterol to campesterol ratios in the plasma, the erythrocytes, the tendon xanthoma and the feces of R. H. were 2.2, 2.2, 2.8, and 2.9, respectively. These ratios were very similar to the $\beta$-sitosterol/campesterol of the patient's diet, which was 2.9. This further suggested that the plant sterols of the blood and tissues of this patient were probably of dietary origin.

The identification of plant sterols. The plasma plant sterols of $\mathrm{L}$. H. and R. H. were tentatively identified by comparing the retention times relative to $5 \alpha$-cholestane to those of pure sterols ${ }^{5}$ on a SE-30 column in a

TABLE X

The $\beta$-Sitosterol Radioactivity in Total Plasma* After an Oral Dose of Isotopic $\beta$-Sitosterol

\begin{tabular}{ccc}
\hline & \multicolumn{2}{c}{ As Percent of dose fed } \\
\cline { 2 - 3 } $\begin{array}{c}\text { Days after } \\
\text { oral isotope }\end{array}$ & $\begin{array}{c}\text { Patient } \\
\text { R. H. }\end{array}$ & $\begin{array}{c}\text { Normal } \\
\text { subject }\end{array}$ \\
\hline 1 & 4.8 & \\
2 & 6.7 & 0.16 \\
4 & 7.1 & \\
5 & 6.9 & \\
6 & & 0.17 \\
9 & 6.6 & 0.18
\end{tabular}

* Plasma volume calculated as $45 \mathrm{ml} / \mathrm{kg}$ body weight (13).

"Total plasma volume calculated as $45 \mathrm{ml} / \mathrm{kg}$ body wt (13).

Obtained as a gift from the Upjohn Co., Kalamazoo, Mich. Purity of the sterols was $>95 \%$. 


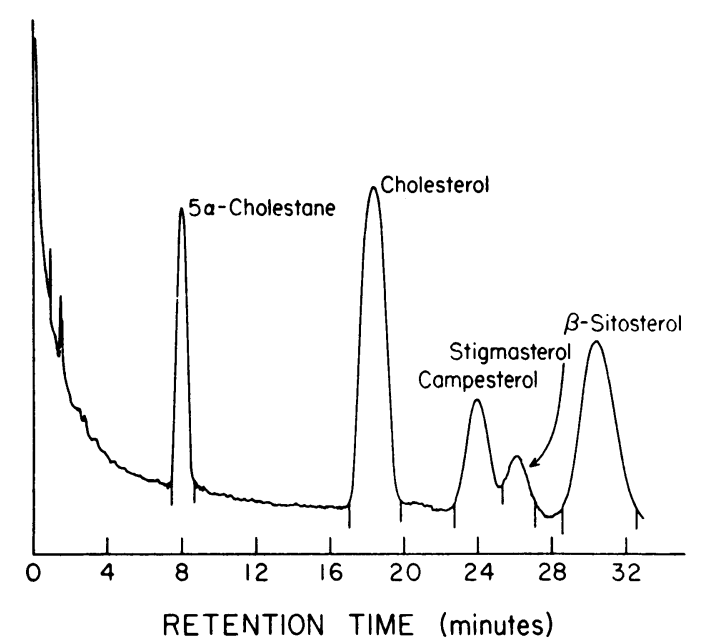

Figure 4 The GLC pattern of plasma sterols of patient L. H. $5 \alpha$-Cholestane was used as the internal standard.

$\mathrm{F}$ and $\mathrm{M}$ high efficiency gas-liquid chromatograph (model 402) (F \& M Scientific Corp., Hewlett-Packard Co., Avondale Div., Avondale, Pa.) The details of GLC conditions have been reported earlier (5). A typical gas chromatogram of the plasma sterols of patient L. H. is shown in Fig. 4. These sterols migrated together on the thin-layer plate and had the same $R_{f}$ value as cholesterol. Addition of a known amount of pure $\beta$-sitosterol to the eluate of this band proportionately accentuated the peak, which we identified as $\beta$-sitosterol in the gas-chromatogram on the basis of retention time relative to $5 \alpha_{-}$ cholestane. The recovery of the added amount of $\beta$-sitosterol was $99.0 \%$. Comparison of the relative retention time (relative to $5 \alpha$-cholestane) of the peak labeled as $\beta$-sitosterol (Fig. 4) to that of pure $\beta$-sitosterol either as free sterol or as the TMS derivative with SE-30 $(3.8 \%)$ and $\mathrm{QF}-1$ (2\%) columns under similar conditions also supported the identification.

The identities of the plasma plant sterols of L. H. and R. H. were further confirmed by combined gas chromatography-mass spectrometry. The principal ions of fragmentation of the TMS derivatives of the plant sterols, $\beta$-sitosterol, campesterol, and stigmasterol and that of cholesterol were identical with those of authentic plant sterols ${ }^{5}$ and cholesterol $^{6}$ and agreed with those reported by Brooks, Horning, and Young (14).

\section{DISCUSSION}

Two basic questions must be asked about the problem of $\beta$-sitosterolemia and xanthomatosis in these two sisters. First, what was the origin of the high levels of plant sterols in their blood and tissues? Second, why did

\footnotetext{
- Obtained from the National Bureau of Standards, Washington, D. C., $>99 \%$ pure.
}

these two sisters develop extensive tendon and tuberous xanthomatosis when their serum cholesterol and triglyceride levels were normal?

There are three possibilities as to the origin of plant sterols in the body: (a) They may be derived from the diet because of increased intestinal absorption. (b) Their excretion into the bile by the liver either as neutral sterols or bile acids may somehow be blocked so that accumulation in the blood and tissues may occur. In fundamental metabolic studies in man, Salen, Ahrens, and Grundy found that about $20 \%$ of the absorbed $\beta$-sitosterol was ultimately converted to bile acids with the remainder excreted in the bile as the free sterol. This excretion has been shown to be more rapid than that of cholesterol (3). (c) Finally, plant sterols could conceivably be synthesized in the tissues of the body. There is no evidence to date that any animal or human tissues synthesize plant sterols (3); only plants have this capacity (15).

It is known that only small amounts $(<5 \%)$ of $\beta$-sitosterol are absorbed by man and that only trace amounts appear in the blood. There was greatly increased intestinal absorption of $\beta$-sitosterol in both of these sisters to provide experimental support for our hypothesis that increased absorption of $\beta$-sitosterol must be considered as a major cause of the $\beta$-sitosterolemia. Furthermore, the question may be raised as to whether the primary defect in this disease might well be an increased capacity to absorb all neutral sterols, including cholesterol. The intestinal absorption of cholesterol could be carried out in only one sister, R. H. It was $66 \%$ of a single oral dose. This value falls in the higher range of cholesterol absorption values obtained in this laboratory $(>60 \%$ cholesterol absorption occurred in only $14 \%$ of all humans studied, normals and type II hypercholesterolemic patients) (11). Probably, then, in this disease, $\beta$-sitosterolemia, one of the chief defects must lie in the intestinal mucosa. However, we cannot rule out that the excretion of $\beta$-sitosterol is impaired, a circumstance that would also favor the accumulation of plant sterols in the body. This possibility is under intensive investigation at present.

Why did these two patients have increased intestinal absorption of plant sterols? On the basis of the events involved in cholesterol absorption, the specificity determining the rate of $\beta$-sitosterol absorption could lie in any one of the following four steps: ( $a$ ) partition of $\beta$-sitosterol between an oil and a micellar phase of the intestinal contents; $(b)$ its uptake by the mucosal cell membranes; $(c)$ its esterification in the mucosal cells; $(d)$ its transport in chylomicrons.

All of the above four steps must have been carried out effectively for the increased absorption of plant sterols to have occurred in these two sisters. Borgström showed that the partition coefficient of $\beta$-sitosterol be- 
tween micellar and oil phases of intestinal contents is similar to that of cholesterol (16). Thus, the state of the sterol in the intestinal lumen cannot explain the difference in the absorption of $\beta$-sitosterol and cholesterol in normal humans. The mode of transfer of sterols from micelles into mucosal cells is not known. There is evidence that mucosal cells can discriminate in their uptake of individual free sterols such as cholesterol and plant sterols $(17,18)$. Although the nature of this discriminatory process has not yet been elucidated, Glover and Green have proposed that the sterol absorption might be mediated via carrier lipoproteins and these lipoproteins might be specific for various sterols (19). However, there is evidence that $\beta$-sitosterol is taken up by mucosal cells (3). The carrier protein, of course, might be important in several of the steps in cholesterol absorption, including the formation of chylomicrons.

The third event in the absorption of sterols, namely the esterification of the sterols in the intestinal cells by cholesterol esterase, may well be the factor limiting $\beta$-sitosterol absorption (3). $\beta$-Sitosterol has been shown to be esterified to a lesser extent than cholesterol in the intestinal mucosal cells of rat $(20,21)$. Swell, Trout, Field, and Treadwell showed that while $\beta$-sitosterol, like cholesterol, is taken up by the intestinal wall, cholesterol is largely esterified before incorporation into chylomicrons. $\beta$-sitosterol, on the other hand, is apparently not esterified in the intestinal wall (22). Kuksis and Huang, studying dogs with thoracic duct fistulas, observed that virtually all of the plant sterols in chyle were unesterified, whereas most of the cholesterol in chyle was esterified (23). However, epicholesterol, a structural analogue of cholesterol, which is not esterified by the pancreatic cholesterol esterase, is absorbed in significant amounts (24), thus suggesting that esterification of a sterol in the intestinal mucosal cells may not always be an obligatory reaction for its absorption. Additional evidence that esterification may be the critical step in the usual failure of $\beta$-sitosterol absorption lies in the fact that this sterol prevents the absorption of cholesterol by preventing its esterification (25). The exact mechanism of this competition is not known. Reviewing all of the available evidence, we would suggest that the one reasonable hypothesis to account for the enhanced absorption of plant sterols in these two sisters involves their esterification and incorporation into chylomicrons.

It has been suggested that $\beta$-sitosterol is an "ideal" internal standard to correct for degradative losses of cholesterol in sterol balance studies (26). One of the primary reasons for the use of $\beta$-sitosterol as an internal standard in the sterol balance studies is that man absorbs hardly any plant sterols from the diet $(2,3)$. The present study indicates such was not the case in these two sisters, since both absorbed large amounts of plant sterols from the diet. In such patients $\beta$-sitosterol cannot be used as marker to correct for sterol "degradation losses" in the gut. In these two sisters we cannot rule out the possibility of some sterol degradation which, if it occurred, would make $\beta$-sitosterol absorption appear greater than it actually was. However, we do not believe that degradation significantly could have affected the absorption test results. First, the blood levels of $\left[4-{ }^{14} \mathrm{C}\right]-$ $\beta$-sitosterol give strong additional evidence of absorption, and second, both the sisters were consuming a mixed food diet at the time that the measurements of the intestinal absorption of $\beta$-sitosterol were carried out. Several previous studies have indicated that with mixed, solid food diets, no degradation of $\beta$-sitosterol or cholesterol occurs in the intestine of man (27-29). Degradation of cholesterol and $\beta$-sitosterol apparently occurs in men fed only formula diets $(27,30)$.

As regards the inheritance of this disease, the parents of these two sisters did not have $\beta$-sitosterolemia and xanthomas. The parents had total plasma plant sterol concentrations well within the normal range (see results) and similar to the values reported, $0.3-1.73 \mathrm{mg} /$ $100 \mathrm{ml}$ of $\beta$-sitosterol, for eight patients ingesting the typical American diet (3). Thus, the occurrence of this disease in two sisters with unaffected parents suggests an inherited recessive trait.

The formation of tendon and tuberous xanthomas are poorly understood, even in hyperlipidemic states with which they are usually associated. The possible mechanisms include increased biosynthesis of cholesterol locally, decreased removal of cholesterol, or an increased affinity for cholesterol derived from the blood by the cells within the tissue. Current evidence suggests that xanthomas develop from imbibition of the plasma lipids by tissues in areas under physical stress and not from increased synthesis or decreased removal of cholesterol (31). The two sisters reported herein had extensive tendon and tuberous xanthomatosis but normal plasma cholesterol concentrations. The tendon xanthomas and adipose tissue contained plant sterols. Despite the high concentration of $\beta$-sitosterol in the xanthomas, the increase in xanthoma cholesterol was quantitatively more important, because cholesterol was the predominant sterol. Perhaps the accumulation of plant sterols in the tendons and skin may have initiated further cholesterol deposition in these tissues, either by attracting cholesterol from plasma by way of net transfer or by stimulating biosynthesis of cholesterol locally. Both processes could occur in the presence of normal plasma cholesterol levels. Perhaps the high concentration of plant sterols in the plasma may have affected the stability of both cholesterol and plant sterols in the circulating lipoprotein complex, thus favoring the deposition of these sterols into the tissues forming xanthomas. Tendon xanthomatosis with normal or low plasma cholesterol levels has also been described in cerebrotendinous xanthomatosis 
(32-35). In this disease still another sterol, cholestanol, accumulates in the tissues in company with cholesterol. The two sisters reported herein did not have cholestanol in either the blood or the xanthomas analyzed.

In this context, the role of plant sterols in the development of atherosclerotic vascular disease should also be considered. It is possible in the light of the above discussion of xanthomas that these sterols may also favor deposition of cholesterol in the arteries producing athersclerotic lesions at an early age. However, at the present time, there is no evidence to support this hypothesis, nor do we know the prognosis of this disease, $\beta$-sitosterolemia and xanthomatosis, as described in this report.

\section{ACKNOWLEDGMENTS}

The expert technical assistance of Mrs. Mary Jo Garst, Mr. Don Lin, and Mrs. Sandra Whitehill is gratefully acknowledged. We are grateful to Dr. Donald Wiebe for his help in the interpretation of the mass spectra.

Dr. Connor was a recipient of U. S. Public Health Service Research Career Development Award HE-18406 from the National Heart and Lung Institute, Bethesda, Md. This study was supported by research grants from the U. S. Public Health Service, National Heart and Lung Institute (HE-14,230), and from the General Clinical Research Centers Program (M01-FR-59) of the Division of Research Resources, National Institutes of Health, Bethesda, Md.

\section{REFER ENCES}

1. Connor, W. E. 1968. Dietary sterols: their relationship to atherosclerosis. J. Am. Diet. Assoc. 52: 202.

2. Gould, R. G., R. J. Jones, G. V. LeRoy, R. W. Wissler, and C. B. Taylor. 1969. Absorbability of $\beta$-sitosterol in humans. Metabolism. 18: 652 .

3. Salen, G., E. H. Ahrens, Jr., and S. M. Grundy. 1970. Metabolism of $\beta$-sitosterol in man. J. Clin. Invest. 49: 952.

4. Abell, L. L., B. B. Levy, B. B. Brodie, and F. E. Kendall. 1952. A simplified method for the estimation of total cholesterol in serum and demonstration of its specificity. J. Biol. Chem. 195: 357.

5. Bhattacharrya, A. K., W. E. Connor, and A. A. Spector. 1972. Excretion of sterols from the skin of normal and hypercholesterolemic humans: implications for sterol balance studies. J. Clin. Invest. 51: 2060.

6. Rose, H. G., and M. Oklander. 1965. Improved procedure for the extraction of lipids from human erythrocytes. J. Lipid Res. $6: 428$.

7. Havel, R. J., H. A. Eder, and J. H. Bragdon. 1955. The distribution and chemical composition of ultracentrifugally separated lipoproteins in human serum. $J$. Clin. Invest. 34: 1345.

8. Burstein, M., H. R. Scholnick, and R. Morfin. 1970. Rapid method for the isolation of lipoproteins from human serum by precipitation with polyanions. J. Lipid Res. 11: 583.

9. Hirsch, J., J. W. Farquhar, E. H. Ahrens, Jr., M. L. Peterson, and W. Stoffel. 1960. Studies of adipose tissue in man. A microtechnic for sampling and analysis. Am. J. Clin. Nutr. 8: 499.

10. Meittinen, T. A., E. H. Ahrens, Jr., and S. M. Grundy. 1965. Quantitative isolation and gas-liquid chromatographic analysis of total dietary and fecal neutral steroids. J. Lipid Res. 6: 411.

11. Connor, W. E., and D. Lin. 1974. The intestinal absorption of dietary cholesterol by hypercholesterolemic (type II) and normocholesterolemic humans. J. Clin. Invest. 54 : 1062.

12. Glomset, J. A. 1970. Physiological role of lecithincholesterol acyltransferase. Am. J. Clin. Nutr. 23: 1129.

13. Edelman, I. S., and J. Liebman. 1959. Anatomy of body water electrolytes. Am. J. Med. 27: 256.

14. Brooks, C. J. W., E. C. Horning, and J. S. Young. 1968. Characterization of sterols by gas chromatography-mass spectrometry of the trimethylsilyl ethers. Lipids. 3: 391.

15. Nicholas, H. J. 1967. The biogenesis of terpenes in plants. In Biogenesis of Natural Compounds. P. Bernfeld, editor. Pergamon Press, New York. 2nd edition. $14: 829$.

16. Borgstrom, B. 1967. Absorption of fats. Proc. Nutr. Soc. $26: 34$.

17. Borgstrom, B. 1968. Quantitative aspects of the intestinal absorption and metabolism of cholesterol and $\beta$ sitosterol in the rat. J. Lipid Res. 9: 473.

18. Subbiah, M. T. R. 1973. Dietary plant sterols: current status in human and animal sterol metabolism. Am. J. Clin. Nutr. 26: 219.

19. Glover, J., and C. Green. 1957. Sterol metabolism. III. The distribution and transport of sterols across the intestinal mucosa of the guinea pig. Biochem. J. 67: 308.

20. Hernandez, H. H., and I. L. Chaikoff. 1957. Purification and properties of pancreatic cholesterol esterase. $J$. Biol. Chem. 228: 447.

21. Murthy, S. K., and J. Ganguly. 1962. Studies on cholesterol esterases of the small intestine and pancreas of rat. Biochem. J. 83: 460 .

22. Swell, L., E. C. Trout, Jr., H. Field, Jr., and C. R. Treadwell. 1959. Absorption of $\mathrm{H}^{3}-\beta$-sitosterol in the lymph fistula rat. Proc. Soc. Exp. Biol. Med. 100: 140.

23. Kuksis, A., and T. C. Huang. 1962. Differential absorption of plant sterols in the dog. Can. J. Biochem. 40: 1493.

24. Hernandez, H. H., I. L. Chaikoff, W. G. Dauben, and S. Abraham. 1954. The absorption of $\mathrm{C}^{12}$-labeled epicholesterol in the rat. J. Biol. Chem. 206: 757.

25. Hernandez, H. H., D. W. Peterson, I. L. Chaikoff, and W. G. Dauben. 1953. Absorption of cholesterol-4$\mathrm{C}^{14}$ in rats fed mixed soybean sterols and $\beta$-sitosterol. Proc. Soc. Exp. Biol. Med. 83: 498.

26. Grundy, S. M., E. H. Ahrens, Jr., and G. Salen. 1968. Dietary $\beta$-sitosterol as an internal standard to correct for cholesterol losses in sterol balance studies. $J$. Lipid Res. 9: 374.

27. DenBesten, L., W. E. Connor, T. H. Kent, and D. Lin. 1970. Effect of cellulose in the diet on the recovery of dietary plant sterols from the feces. $J$. Lipid Res. $11: 341$.

28. Kudchodkar, B. J., H. S. Sodhi, and L. Horlick. 1971. Absorption of dietary cholesterol in man. Circulation. 44 (Suppl. II) : II-10 (Abstr.)

29. Kottke, B. A., and M. T. Ravi Subbiah. 1972. Sterol 
balance studies in patients on solid diets: comparison of two "nonabsorbable" markers. J. Lab. Clin. Med. $80: 530$.

30. Ahrens, E. H., Jr. 1970. A review of the evidence that dependable sterol balance studies require a correction for the losses of neutral sterols that occur during intestinal transit. In Atherosclerosis: Proceedings of the Second International Symposium. R. J. Jones, editor. Springer-Verlag, New York. 248.

31. Wilson, J. D. 1963. Studies on the origin of the lipid components of xanthomata. Circ. Res. 12: 472.

32. Schimschock, J. R., E. C. Alvord, Jr., and P. D.
Swanson. 1968. Cerebrotendinous xanthomatosis. Clinical and pathological studies. Arch. Neurol. 18: 688.

33. Menkes, J. H., J. R. Schimschock, and P. D. Swanson. 1968. Cerebrotendinous xanthomatosis. The storage of cholestanol within the nervous system. Arch. Neurol. 19 : 47.

34. Philippart, M., and L. van Bogaert. 1969. Cholestanolosis (cerebrotendinous xanthomatosis). A follow-up study on the original family. Arch. Neurol. 21: 603 .

35. Salen, G. 1971. Cholestanol deposition in cerebrotendinous xanthomatosis. A possible mechanism. Ann. Intern. Med. 75 : 843. 